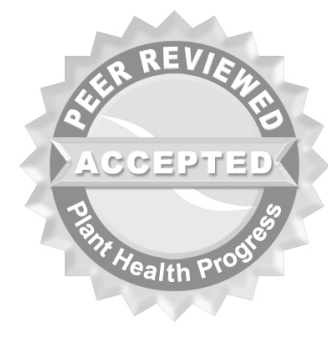

(C) 2006 Plant Management Network.

Accepted for publication 20 July 2006. Published 16 October 2006.

\title{
Influence of Messenger on Corn Yield and Mycotoxin Contamination in Mississippi
}

\author{
Hamed K. Abbas and H. Arnold Bruns, Crop Genetics and \\ Production Research Unit, and Craig A. Abel, Southern Insect \\ Research Unit, USDA-ARS, P.O. Box 346, Stoneville, MS 38776 \\ Corresponding author: Hamed K. Abbas. habbas@ars.usda.gov
}

Abbas, H. K., Bruns, H. A., and Abel, C. A. 2006. Influence of Messenger on corn yield and mycotoxin contamination in Mississippi. Online. Plant Health Progress doi: 10.1094/PHP2006-1016-03-RS.

\begin{abstract}
Harpin, a bacterial protein that elicits systemic acquired resistance increasing plant disease resistance in several species, is reported to enhance yield and quality of several crops including corn (Zea may L.). This experiment examined the effect of Harpin on corn yield, suppression of aflatoxin and fumonisin contamination, and Aspergillus colonization in corn grain. The experiment was conducted in 2002 and 2003 on two different soils at Stoneville, MS. Plots of a commercial corn hybrid were inoculated with Aspergillus flavus strain F3W4, formulated on autoclaved wheat (Triticum aestivum $L$ ) kernels, and applied to the soil surface at growth stages V5-V6 of the corn. Fusarium verticillioides was allowed to infect the grain naturally. Harpin was applied at a rate of $160 \mathrm{~g} / \mathrm{ha}$ as a spray over the top of corn plants at growth stages V1 to V2 and again at V5 to V6. No differences in yield were observed nor did harpin have any effect on aflatoxin or fumonisin contamination. Aspergillus colonization was unaffected by harpin at one site and was lower than the untreated controls when applied at growth stages $\mathrm{V} 1$ to $\mathrm{V} 2$ at the other.

\section{I ntroduction}

Harpin, a bacterial protein sold under the trade name Messenger (Eden Bioscience, Bothell, WA), is reported to increase yields in corn, rice (Oryza sativa L.), cotton (Gossypium hirsutum L.), tomatoes (Lycopersicon esculentum Mill.), strawberry (Fragaria virginiana Duchesne), and grapes (Vitis spp.) $(12,13,24,25,26)$. The active ingredient was first isolated from Erwinia amylovora $(14,25)$. In higher plants, harpin causes a hypersensitive response that results in disease resistance $(5,17)$. It has also been shown to stimulate growth in some plant species, increasing size and accelerating the rate of development (17).

Harpin is thought to protect plants against disease by stimulating an induced resistance. Harpin has been demonstrated to increase resistance of tobacco (Nicotiana tabacum L.) plants to tobacco mosaic virus (27) and Arabidopsis plants to Pseudomonas syringae $(10,11)$. Genetic resistance to fungal, bacterial, nematode, and viral infections are also induced by harpin $(6,21,25,27)$. In one study, harpin application was noted to increase plant growth $(12,13)$. In field trials, this effect on growth has resulted in higher yields (12). Also, researchers at Eden Bioscience, the makers of Messenger, claim that it consistently increases several physiological processes in a variety of crops such as photosynthesis and nutrient uptake (12).

Economic losses in corn caused by Aspergillus and Fusarium ear rots $(3,16,18)$ can be large, in part because of the production of aflatoxin and fumonisins by these respective species (20). Corn grain contaminated by these fungi and their respective mycotoxins can cause toxicological problems for livestock $(1,8)$. Federal guidelines by the FDA prohibit the use of corn with aflatoxin greater than $20 \mathrm{ppb}$ (23) and fumonisin greater than $2 \mathrm{ppm}$ (22).

The objectives of this study were to determine if harpin could increase corn yields, suppress aflatoxin and fumonisin contamination of the grain, and Aspergillus colonization in corn grain.
\end{abstract}


Treatment of Corn with Harpin

The corn hybrid Pioneer 32R25, was planted at two sites on Mississippi State University's Delta Branch Experiment Station near Stoneville, MS. Site 1 was on a Dundee silty clay soil (fine-silty, mixed, thermic Aeric Ochraqualfs) prepared for planting by forming $40-\mathrm{cm}$ ridges spaced $76 \mathrm{~cm}$ apart. Site 2 was a Beulah fine sandy loam soil (coarse-loamy, mixed thermic Typic Dystrochrepts) prepared for planting by forming 50 -cm ridges spaced $102 \mathrm{~cm}$ apart. Planting occurred on 19 April 2002 and 16 April 2003 at both sites. The experimental design was a randomized complete block replicated four times. Individual plots were six rows $9 \mathrm{~m}$ long and eight rows $18 \mathrm{~m}$ long for Sites 1 and 2, respectively.

Approximately $56 \mathrm{~kg}$ of $\mathrm{K}$ per ha as murate potash and $112 \mathrm{~kg}$ of $\mathrm{N}$ per ha as $\mathrm{NH}_{4} \mathrm{NO}_{3}$ were applied pre-plant, followed by an additional $112 \mathrm{~kg}$ of $\mathrm{N}$ per ha of $\mathrm{N}$ as $\mathrm{NH}_{4} \mathrm{NO}_{3}$ : urea liquid formulation at growth stage V6 (19). Weeds were controlled by application of the herbicide Permit (halosulfuron, Monsanto, St Louis, MO) at $93 \mathrm{~g} / \mathrm{h}$ h to Site 1 and Bicep II (atrazine + metolachlor, Monsanto Co., St. Louis, MO), at 4.7 liter/ ha to Site 2. Furrow irrigation at the rate of approximately $25 \mathrm{~mm}$ per irrigation, was applied at both sites in 2002 and 2003 beginning at growth stage R1 using a schedule previously defined (7). Plant populations in both fields were achieved by over planting $200 \%$ and then thinning to a density of $\sim 71,500$ plants/ha.

A strain of Aspergillus flavus (F3W4) known to produce aflatoxin was used for inoculations in this experiment (2). The fungus was formulated on autoclaved wheat (Triticum aestivum L.) and applied at a rate of $22.4 \mathrm{~kg} / \mathrm{ha}$ to the four center rows of each plot at grouth stage V5 to V6 (4). Fusarium verticilliodes, a fungus commonly associated with fumonisin contamination of corn, was allowed to infect naturally. Harpin was applied to the four center rows of selected plots using a $\mathrm{CO}_{2}$ pressurized backpack sprayer delivering approximately 187 liter/ ha at $0.14 \mathrm{MPa}$. The treatments were: (i) $160 \mathrm{~g} / \mathrm{ha}$ harpin at V1 to V2 growth stage; (ii) $160 \mathrm{~g} /$ ha harpin at V1 to V2 growth stage plus fungal inoculum; (iii) $160 \mathrm{~g} /$ ha harpin at V5 to V6 growth stage; (iv) 160 $\mathrm{g} /$ ha harpin at V5 to V6 growth stage plus fungal inoculum; (v) untreated control; and (vi) untreated control with fungal inoculum.

The four center rows from each plot were harvested for yield and a $0.5-\mathrm{kg}$ grain sample was collected to determine grain moisture content, grain bulk density, Aspergillus colonization and mycotoxin contamination. Yields were adjusted to $15.5 \%$ moisture. Data were analyzed using Mix Model Analysis of Variance (PROC MIXED, v. 9.1, SAS Institute Inc., Cary, NC).

\section{Grain Yield}

Harpin had no effect on grain yield at either site in both years of the experiment (Table 1). Yields did tend to be greater $(P \leq 0.05)$ on the Beulah fine sandy loam of Site 2 (9607 kg/ ha in 2002 and $9444 \mathrm{~kg} / \mathrm{ha}$ in 2003) than the Dundee silty clay at Site 1 (7659 kg/ ha in 2002 and $8286 \mathrm{~kg} / \mathrm{ha}$ in 2003). However, no improvement in corn yields as a result of harpin application were observed, as has been reported in other crops.

Table 1. Analyses of variance $P$ values for harpin treatments on yields, aflatoxin concentrations, fumonisin concentrations, and Aspergillus flavus populations for corn grown with furrow irrigation in 2002 and 2003 at Stoneville, MS.

\begin{tabular}{|l|c|c|c|c|c|}
\hline Source & Df & Yield & [Aflatoxin] & [Fumonisin] & A. flavus \\
\hline Year & 1 & 0.46 & 0.20 & 0.10 & 0.47 \\
\hline Site & 1 & $\leq 0.01$ & 0.17 & $\leq 0.01$ & 0.04 \\
\hline Treatment & 5 & 0.31 & 0.76 & 0.66 & 0.03 \\
\hline Treatment x year & 5 & 0.39 & 0.69 & 0.77 & 0.31 \\
\hline Treatment x site & 5 & 0.58 & 0.67 & 0.09 & 0.02 \\
\hline Site x year & 1 & 0.02 & 0.80 & 0.13 & 0.46 \\
\hline Treatment x site $x$ year & 5 & 0.05 & 0.16 & 0.07 & 0.17 \\
\hline
\end{tabular}


Mycotoxin Analyses and Fungal I solation

After harvesting, all grain samples were analyzed for the presence of aflatoxin and fumonisin. Analyses for the mycotoxins were conducted using ELISA (Vertox, Neogen Crop., Lansing, MI) (3). Data were analyzed using Mixed Model Analysis of Variance (PROC MIXED, v. 9.1, SAS Institute Inc., Cary, NC). Log transformations were conducted on aflatoxin concentrations to facilitate statistical analyses.

No differences in aflatoxin contamination levels were observed among various harpin treatments or when compared with the untreated control (Table 1). Contamination levels ranged from $5.0 \mathrm{ppb}$ to $93.2 \mathrm{ppb}$ with an overall average of $47.3 \mathrm{ppb}$. Differences $(\mathrm{P} \leq 0.01)$ in fumonisin contamination were noted between Site 1 ( $26.7 \mathrm{ppm}$ ) and Site 2 (44.3 ppm). No other group of means was significantly different for fumonisin.

\section{Aspergillus Populations}

Aspergillus flavus strains were isolated and their populations calculated from all corn samples and expressed as colony forming units per gram (CFUs/g) similar to procedures of Horn and Doner (15). The treatment $\times$ site interaction was statistically significant $(\mathrm{P} \leq 0.05)$ for $\mathrm{CFUs} / \mathrm{g}$ (Table 1$)$. No differences in $\mathrm{CFUs} / \mathrm{g}$ among treatments were observed at Site 1 . At Site 2, the CFUs/ $g$ for the harpin treatments at V1-V2 were less $(\mathrm{P} \leq 0.05)$ than the untreated controls (Table 2). The CFUs/ $g$ were also less for the harpin treatment at V1-V2 than at V5-V6 in the non-inoculated treatment but did not differ in the inoculated treatment. The CFUs/ $g$ at Site 2 were greater than at Site 1 when harpin was not applied. Toxigenic and non-toxigenic strains of A. flavus were determined from the plots according to procedures outlined by Abbas et al. (2).

Table 2. Effect of harpin treatment at two growth stages on A. flavus populations measured as colony forming units (CFUs/g) on grain from furrow irrigated corn grown at two sites near Stoneville, MS. ${ }^{x}$

\begin{tabular}{|l|c|c|c|c|c|c|}
\hline \multirow{4}{*}{} & \multicolumn{5}{|c|}{ Colony forming units (CFUs/g) } \\
\cline { 2 - 7 } & \multicolumn{3}{|c|}{ Non-inoculated } & \multicolumn{2}{c|}{ I noculated with Aspergillus flavus } \\
\cline { 2 - 7 } & $\begin{array}{c}\text { Harpin } \\
\text { at V1-V2 }\end{array}$ & $\begin{array}{c}\text { Harpin } \\
\text { at V5-V6 }\end{array}$ & $\begin{array}{c}\text { No } \\
\text { harpin }\end{array}$ & $\begin{array}{c}\text { Harpin } \\
\text { at V1-V2 }\end{array}$ & $\begin{array}{c}\text { Harpin } \\
\text { at V5-V6 }\end{array}$ & $\begin{array}{c}\text { No } \\
\text { harpin }\end{array}$ \\
\hline 1 & 29 & 36 & 12 & 34 & 40 & 34 \\
\hline 2 & 6 & 40 & 61 & 28 & 58 & 68 \\
\hline
\end{tabular}

$x$ Means of four replications.

$y$ LSD at $P \leq 0.05$ for means within a column and a row $=30$.

z Site 1, Dundee silty clay; Site 2, Beulah fine sandy loam.

Both toxigenic and non-toxigenic strains of A. flavus were isolated from grain treated with harpin indicating it had a similar effect on reducing different populations of the fungus.

Based on our results, harpin as used in this study did not increase corn grain yields. This is different from data reported by Cobum (9). Harpin did reduce fungal colonization at Site 2 when applied at growth stage V1-V2. However, harpin failed to protect corn from fungal colonization at Site 1 and did not reduce mycotoxin contamination at either site. Perhaps harpin has less activity on certain plant species. Ahmad et al. (5) stated that biological activity of harpin may be less in monocots than in dicots, and its involvement in pathogenesis is still uncertain. This is the first report of the effect of harpin on corn colonization by Aspergillus and Fusarium species and their toxins.

\section{Acknowledgments and Disclaimer}

Technical assistance by BobbieJ ohnson, Kenya Dixon, Owen Houston, Rodrick Patterson, and Roosevelt J ohnson are acknowledged. Appreciation is also expressed to Mr. Ned French of Eden Bioscience for supplying the Messenger used in this experiment. 
Trade names are used in this publication solely for the purpose of providing specific information. Mention of a trade name, propriety product, or specific equipment does not constitute a guarantee or warranty by the USDA-ARS and does not imply approval of the named product to exclusion of other similar products.

\section{Literature Cited}

1. Abbas, H. K., ed. 2003. Special issue: Aflatoxin and food safety - Part 1. J. of Toxicol, Toxin Rev. 22:139- 459.

2. Abbas, H. K., Zablotowicz, R. M., and Locke, M. A. 2004. Spatial variability of Aspergillus flavus soil populations under different crops and corn grain colonization and aflatoxins. Can. J . Bot. 82:1768-1775.

3. Abbas, H. K., Cartwright, R. D., Xie, W., and Shier, W. T. 2006. Aflatoxin and fumonisin contamination of corn (maize, Zea mays) hybrids in Arkansas. Crop Prot. 25:1-9.

4. Abbas, H. K., Zablotowicz, R. M., Bruns, H. A., and Abel, C. A. 2006. Biocontrol of aflatoxin in corn by inoculation with non-aflatoxigenic Aspergillus flavus isolates. Biocontrol Sci. Tech. 16:437-449.

5. Ahmad, M., Majerczak, D. R., Pile, S., Hoyas, M. E., Novacky, A., and Coplin, D. L. 2001. Biological activity of harpin produced by Pantoea stewartii subsp. stewartii. Molec. Plant-Microbe Interact. 14:1223-1234.

6. Baker, C. J., Orlandi, E. W., and Mock, N. M. 1993. Harpin, an elicitor of hypersensitive response in tobacco caused by Erwinia amylovora, elicits active oxygen production in suspension cells. Plant Physiol. 102:1341-1344.

7. Bruns, H. A., Meredith, W. R., and Abbas, H. K. 2003. Effects of furrow irrigation on corn in the humid sub-tropical Mississippi delta. Online. Crop Management dol:10.1094/CM-2003-1222-02-RS.

8. CAST (Council for Agriculture Science and Technology). 2003. Mycotoxins risks in plant, animal, and human systems. Task Force Report 139. CAST, Ames, IA.

9. Cobum, G. 2002. Messenger corn. EDEN Bioscience. SBU-7012-0061-1-02.02.

10. Desikan, R., Reynolds, A., Hancock, J. T., and Neill, S. J. 1998. Harpin and hydrogen peroxide both initiate programmed cell death but have differential effects on defense gene expression in Arabidopsis suspension cultures. Biochem. J. 330:115-120.

11. Dong, H., Delaney, T. P., Bauer, D. W., and Beer, S. V. 1999. Harpin induces disease resistance in Arabidopsis through the systemic acquired resistance pathway mediated by salicylic acid and the NIMI gene. Plant J . 20:207-215.

12. Eden Bioscience. 2002. The science behind Messenger and Harpin technology a collection of white papers.

13. French, N. 2001. Messenger-Harpin protein use in cotton production. Proc. Beltwide Cotton Conf. 1:47-49

14. He, S-Y., Huang, H-C., and Collmer, A. 1993. Pseudomanas syringae pv. syringae harpin $\mathrm{P}_{\mathrm{ss}}$ : a protein that is secreted via the Hrp-pathway and elicits the hypersensitive response in plants. Cell 73:1255-1266.

15. Horn, B. W., and Doner, J. W. 1998. Soil populations of Aspergillus species from section Flavi along a transect through peanut-growing regions of the United States. Mycologia 90:767-776.

16. Payne, G. S. 1992. Aflatoxin in maize. Crit. Rev. Plant Sci. 10:423-440.

17. Popham, P. L., Pike, S. M., and Novacky, A. 1995. The effect of harpin from Erwinia amylovora on the plasmalemma of suspension-cultured tobacco cells. Physiol. Molec. Plant Pathol. 47:39-50.

18. Reid, L. M., Nicol, R. W. Ouelelet, T., Savard, M., Miller, J. D., Young, J . C., Stewart, D. W., and Schaafsma, A. W. 1999. Interactions of Fusarium graminearum and F. moniliforme in maize ears: Disease progress, fungal biomass, and mycotoxin accumulation. Phytopathology 89:1028-1037.

19. Ritchie, S. W., Hanway, J . J., and Benson, G. O. 1992. How a corn plant develops. Coop. Ext. Serv. Special Rep. No. 48. Iowa State Univ. of Sci. and Tech., Ames, IA.

20. Robens, J., and Cardwell, K. 2003. The costs of mycotoxin management to the USA: Management of aflatoxins in the United States. J . Toxicol., Toxin Rev. 22:139-152.

21. Taguchi, F., Tanaka, R., Kinoshita, S., Ichinose, Y., Imura, Y., Andi, S., Toyoda, K., Shiraishi, T., and Yamada T. 2001. Harpin $\mathrm{P}_{\text {sta }}$ from pseudomonas syringae pv. tabaci: Is defective and deficient in its expression and HR-inducing activity. J . Gen. Plant Pathol. 67:116-123 
22. US Food and Drug Administration (FDA). Guidance for industry: Fumonisin levels in human foods and animal feeds, Final guidance, November 9, 2001. Online. Center for Veterinary Med., Center for Food Safety and Appl. Nutrition, FDA, Washington, DC.

23. Van Egmond, H. P., and J onker, M. A. 2004. Worldwide regulations on aflatoxins: The situation in 2002. J. Toxicol., Toxin Rev. 23:273-293.

24. Wei, Z., and Beer, S. V. 1996. Harpin from Erwinia amylovora induces plant resistance. Acta Hort. 411:221-224.

25. Wei, Z., Lady, R. L., Zumoff, C. H., Nauer, D. W., He, S. Y., Collmer, A., and Beer, S. V. 1992. Harpin, elicitor of the hypersensitive response produced by the plant pathogen Erwinia amylovora. Science 257:85-88.

26. Wright, D. L., Wiatrak, P. J., Grzes, S., and Pudelko, J. 2000. Messenger: A systemic acquired resistance influence on cotton. Pages 617-620 in: Proc. of the Beltwide Cotton Conf., Vol. 1. C. P. Dugger and D. A. Richter, eds. Nat. Cotton Counc. of Am., Memphis, TN.

27. Xie, Z., and Chen, Z. 2000. Harpin-induced hypersensitive cell death is associated with altered mitrochondrial functions in tobacco cells. Molec. Plant-Microbe Interact. 13:183-190. 